Research article

\title{
Family business resilience under the COVID-19: A comparative study in the furniture industry in the United States of America and Colombia
}

\author{
Ana Cristina González* \\ Assistant Professor, Seidman College of Business, Grand Valley State University, Grand Rapids, United States. \\ gonzaana@gvsu.edu \\ Miguel Ángel Pérez-Uribe \\ Asistente de Docencia, Facultad de Ciencias Administrativas y Económicas, Universidad Icesi, Cali, Colombia. \\ maperez@icesi.edu.co
}

\begin{abstract}
COVID-19 has impacted the world and has forced organizations to adapt to the "new normal", and family businesses have not been exempt. In this study, we answer two research questions; how prepared are family businesses to face shocks like the pandemic? and, do contexts matter in that response? Using the Resource-Based View of the firm, in this qualitative exploratory study we analyze the resources and capabilities deployed by two business families owning three family businesses in the office furniture industry in the countries of Colombia and the USA. Our findings indicate that indeed family businesses are resilient, but the resources and capabilities deployed and their uses are different according to the context, suggesting a contingent familiness during a crisis.
\end{abstract}

Keywords: family business; resilience; resource-based view; COVID-19.

Resiliencia en empresas de familia durante COVID-19: un estudio comparativo de la industria de muebles en Estados Unidos y en Colombia

Resumen

COVID-19 ha obligado a las organizaciones a adaptarse a la "nueva normalidad", incluyendo a las empresas familiares. En este estudio, el objetivo es responder dos preguntas: ¿Qué tan preparadas están las empresas familiares para enfrentar disrupciones como la pandemia? y ¿qué tan importante es el contexto en esa respuesta? Utilizando la visión basada en recursos, en este estudio cualitativo se analiza los recursos desplegados por dos familias empresarias propietarias de tres empresas familiares en la industria del mueble en Colombia y Estados Unidos. Los hallazgos evidencian que las empresas familiares son resilientes, pero los recursos y las capacidades desplegados, así como sus usos, son diferentes de acuerdo al contexto, lo que sugiere una familiness contingente durante una crisis.

Palabras clave: empresas familiares; resiliencia; visión basada en recursos; COVID-19.

Resiliência em empresas familiares sob a COVID-19: um estudo comparativo da indústria de móveis nos Estados Unidos da América e na Colômbia

Resumo

A COVID-19 impactou o mundo e obrigou organizações a se adaptarem ao "novo normal", e as empresas familiares não ficaram isentas. Neste estudo, respondemos a duas questões de pesquisa: o quão preparadas estão as empresas familiares para enfrentar choques como o da pandemia e, se os contextos importam nessa resposta Utilizando a Visão Baseada em Recursos da empresa, neste estudo exploratório qualitativo, analisamos os recursos e capacidades implantados por duas empresas familiares proprietárias de outras três empresas familiares da indústria de móveis de escritório nos países da Colômbia e dos EUA. Nossos resultados indicam que, de fato, as empresas familiares são resilientes, mas os recursos e as capacidades implantados, e seus usos, são diferentes de acordo com o contexto, sugerindo uma familiness contingente durante uma crise.

Palavras-chave: empresa familiar; resiliência; visão baseada em recursos; COVID-19.

* Corresponding author.

JEL classification: M10; M16; M19.

How to cite: González, A.C. \& Pérez-Uribe, M.A. (2021). Family business resilience under the COVID-19: A comparative study in the furniture industry in the U.S.A. and Colombia. Estudios Gerenciales, 37(158), 138-152. https://doi.org/10.18046/j.estger.2021.158.4423

DOI: https://doi.org/10.18046/j.estger.2021.158.4423

Received: 16 -oct-2020

Accepted: 3-feb-2021

Available on line: 31 -mar-2021

() 2021 Universidad ICESI. Published by Universidad Icesi, Colombia.

This is an open access article under the CC BY license (http://creativecommons.org/licenses/by/4.0/) 


\section{Introduction}

Virus outbreaks are not new in the world. In fact, there is evidence that they occur within 10 to 50 years intervals and will become more often due to the increase of human population, overcrowded cities, our proximity and often invasion of areas in which other species can transmit new types of viruses, international travel, trade in general, and globalization (Zakaria, 2020). The COVID-19 pandemic forced a lot of businesses foreclosures due to disrupted markets and commercialization for most industries, carrying too many people to poverty, forcing us to rethink the way we live (Donthu \& Gustafsson, 2020). This unpreparedness has become more frustrating since we knew it could happen and we let it go from an outbreak to a pandemic, even though we sanitization and wearing face masks (Zakaria, 2020).

Family businesses have not been exempted from these challenges during the pandemic. They have been considered more capable to respond to disruptions than non-family businesses (Chrisman, Chua, \& Steier, 2011), thus, they tend to be more resilient. Family business resilience is defined as "the reservoir of individual and family resources that cushions the family firm against disruptions and is characterized by individual and collective creativity used to solve problems and get work done" (Brewton, Danes, Stafford, \& Haynes, 2010, p. 156). Unarguably, COVID-19 is a disruption that has forced family businesses to create, reduce, find, and change resources and capabilities to remain sustainable and survive, i.e. to be resilient.

Considering the above, the purpose of this research is to conduct a comparative study of family business resilience during the COVID-19 pandemic. In particular, we aim to answer two research questions. First, how do family businesses face and respond to environmental shocks such as COVID-19? and second, do contexts matter in that response? Using the Resource-Based View (RBV) theory of the firm, through a qualitative exploratory case study approach, we analyze the resources and capabilities deployed by two business families owning three family businesses in the office furniture industry in Colombia and the United States, particularly the State of Michigan. It also focuses on determining similarities and differences, given the two contrasting contexts in which the family businesses operate. In order to do that, we analyze Mzid, Khachlouf and Soparnot (2019) study's dimensions of family business resilience: adaptive capacity, strategic renewal, and appropriation capacity. We believe the pandemic has given us an opportunity to deeper understand family business resilience and determine its particularities in different business settings.

Our findings evidenced that indeed family businesses are resilient despite the lockdowns, the drop in demand and revenues, but the resources and capabilities deployed are different and so are their uses. These differences are driven partly as a consequence of the idiosyncratic bundle of family-driven resources each firm has, also known as familiness (Habbershon, Williams, \& MacMillan, 2003;
Sirmon, Hitt, Ireland, \& Gilbert, 2011), and also partly driven by the context. This finding leads us to suggest a contingent familiness, during the crisis.

This study contributes to opening up the "black box" of family business resilience by explaining why and how business families react and even thrive under extreme pressure during the crisis itself. The first pandemic of the $21^{\text {st }}$ century allowed us to fill three gaps in the literature: First, we supported the Resource-Based View contingent approach (Brush \& Artz, 1999) and expanded on the critique of RBV being context isolated (Rau, 2014), suggesting, as mentioned above, a contingent familiness. This study deems it necessary to expand our knowledge beyond the mainstream research that uses data from developed countries. Second, this comparative research also allowed us to gain an in-depth understanding of why and how family business resilience works by capturing the specificity of resources and capabilities used, the context in which they are used, their purpose, and outcomes. Family business scholars have called for these types of approaches, given that most of what we know in the field is based on quantitative data (De Massis \& Kammerlander, 2020; Nordqvist, Hall, \& Melin, 2009). Third, this study provided evidence of family business heterogeneity (Memili \& Dibrell, 2019) beyond business descriptive and percentage of family involvement in governance, and allowed us to understand the country, industry, business, and family factors altogether and their influence on the family business system.

As follows, we present our literature review, focusing on RBV and family business resilience, followed by our method, context analysis, results, and discussion sections. We finalize presenting our conclusions, which include limitations and future research.

\section{Literature review}

\subsection{The RBV of family businesses under environmental crises}

As we mentioned earlier, our study uses the RBV of the firm to help our understanding of how family businesses react to face environmental shocks such as the pandemic, and if that response is determined by the context in which they operate. The RBV as a theory of the firm sees it as a unique set of resources that allows the firm to formulate strategies to compete, suggesting an internal approach to strategy, instead of the strong external focus on the market that led the strategy field for years (Penrose, 1959; Wernerfelt, 1984).

The RBV suggests that firms achieve competitive advantage through the configuration of a bundle of resources and capabilities that make what they do and offer valuable, rare, inimitable, and non-substitutable (VRIN) (Barney, 1991). According to Grant (1991), in order to establish a competitive advantage, a firm should identify, classify, and decide its VRIN set of resources and capabilities to develop a strategy that fills a market gap. Such configurations can be affected for good and for bad 
when environmental disruptions such as COVID-19 occur. In some cases, they may have a positive effect on the firm's response to the disruption, while in others they might constraint the firm's reaction.

Building into this point, Brush and Artz (1999), found that those resources that generate competitive advantage are contingent upon the industry's information asymmetries, implying that contextual factors, outside of the control of the firm, play a role on the firm's competitive advantage and the effectiveness of its resources and capabilities. They suggest a contingent RBV, meaning that the bundle of resources creates advantages subject to certain external conditions.

Following this contingent RBV approach, BrandonJones, Squire, Autry, and Petersen (2014) suggest that national context and culture, firm size, and strategic context are contingency factors that affect the firm's bundle of resources, and consequently their reactions to disruptions, i.e. their resilience. In their empirical study about supply chain resilience, they found that factors associated with the industry value chain, such as geographic dispersion and scale and delivery complexity, moderate the relationship between firms' supply chain resources and capabilities and its resilience (Brandon-Jones et al., 2014).

Specifically, in family firms, the RBV has been a key theoretical approach, given that the family itself has been considered a VRIN resource that can help the family business achieve competitive advantage (Habbershon \& Williams, 1999). Moreover, based on the RBV, the construct of familiness was defined as the idiosyncratic bundle of resources and capabilities that result from the interaction between the family and the business, which adds value to the family business (Habbershon et al., 2003). Nevertheless, familiness has not been a construct without controversy. First, because it includes all and any kind of resources, which means no specificity signals if it is the resources themselves that provide an advantage or if they serve as resources to access other resources. Second, some scholars argue that not all resources brought by the family are positive for the family business (Rau, 2014). In this regard, Sirmon et al. (2011) suggest not to focus on specific resources, but on resource orchestration, which is the particularity that can provide family businesses with an edge when facing competition. The above builds on the idea that the family brings resources and capabilities to the business, that such influence could be good or bad for the business, and that it is not about a specific resource, but their orchestration which makes them VRIN and provides the family firm with an advantage in comparison to their counterparts (Rau, 2014).

Acquaaha, Amoako-Gyampah, and Jayaram (2011) in comparing family and non-family business responses to disruptions argue that it is not that one is more capable than the other, or one has better resources than the other, but that they leverage different types of resources to cope with and respond to changes in the business environment. While family businesses leverage their reputational capital to deal with an environmental shock, such as getting bank loans to secure working capital during the crisis, nonfamily businesses rely on building redundancies, such as having multiple suppliers, which provides a stronger bargaining position with them.

In sum, the RBV as a theory of the firm and familiness as a construct driven from the theory, can be influenced and affected by the context in which the family business operates and more interestingly, if faced by a pandemic that changed things for good in the business landscape, such shock would influence the resource orchestration, or the familiness, and either support or constraint the family business resilience.

\subsection{Family business resilience}

The capacity of the family business to respond to a disruption depends on its resilience, defined by Brewton et al. $(2010$, p. 156) as "the reservoir of individual and family resources that cushions the family firm against disruptions and is characterized by individual and collective creativity used to solve problems and get work done". This "reservoir" is the result of a continuous flow between the family and the business interactions, in which resources and capabilities are put into play. Thus, it is a result of an arising process in which the business family finds solutions and uses, and develops resources to cope with defiant scenarios through the enhancement of family management practices (Patterson, 2002).

This view concurs with the RBV and the familiness construct (Habbershon et al., 2003). Those aforementioned flows of resources stored include both the firm's and the family's social, human, and financial capital, as well as the family's socioemotional wealth, i.e. the family's emotional endowments on the firm (Gómez-Mejía, Haynes, NúñezNickel, Jacobson, \& Moyano-Fuentes, 2007), that build the stock of family business resilience and allow the family business survival in front of a new situation (Brewton et al., 2010; Sirmon \& Hitt, 2003). For instance, Paul, Winter, Miller, and Fitzgerald (2003) signal that the organizational system of resources is mutually embedded between the family and the business, and could be definitive to the family firm's response and success in the occurrence of disruptions (Olson et al., 2003). Moreover, according to Danes, Loy, and Stafford (2008) the lack of these capabilities, can affect the family business' efficiency and weaken synergies among business family members and the family firm to face both internal and external disturbances (Danes et al., 2008).

The family business management strategies, its rules, and the interactions and behaviors of the business family to face disruptions are a consequence of the adaptation of their policies based on the experience of both family and firm and they are precisely the kind of actions or flows that develop and improve the resilience capacity of the family business (Brewton et al., 2010; Moen \& Wethington, 1992). According to Danes, Rueter, Kwon, and Doherty (2002), the family firm that has developed resilience can use these "stored" abilities to face troubles faster and easier than other firms, facing and adapting their routines and 
practices. Those abilities have a higher effect than a simple sum of resources, since these resources and capabilities can be combined and permuted in diverse circumstances, and their reconfiguration could result in higher returns (Danes et al., 2009).

Regarding the characteristics of family business resilience, when compared to non-family businesses, literature has found that family businesses have stronger linkages to the past (Mzid et al., 2019) and they highly value tradition, evidenced by their low levels of investment in research and development (Duran, Kammerlander, Van Essen, \& Zellweger, 2016). Despite that, family businesses are prone to have higher levels of resilience (Chrisman et al., 2011), given their desire to transfer ownership and management to future generations (Steier, 2005) which makes them adapt, cope, and even thrive under strain circumstances. The above concurs with the contingent RBV approach discussed in the previous section since these characteristics attest not only that familiness can be positive or negative, but that family business resources and capabilities perceived as negative can become positive in a moment of distress and make the family business more resilient.

As well, management succession strategies, social capital, socioemotional wealth, expertise and opportunity identification, and long-term orientation have been characteristics of resilient family businesses (Chrisman et al., 2011). In the same line, Patel and Fiet (2011) suggest that aspects such as noneconomic goals, altruism, social capital, and family succession contribute to family firm resilience, given their positive impact on governance structures, which makes possible the construction of advantages despite adversity (Chrisman et al., 2011).

Lengnick-Hall and Beck (2009) found that resilient family businesses can absorb and capitalize on environmental changes to guarantee stability and continuity in situations of uncertainty and chaos. They state that the access to human, social and financial capital that both the family and the business have, contribute to their sustainability (Danes et al., 2009; Lengnick-Hall \& Beck, 2009; Mzid et al., 2019). These same authors suggest that family firms' resilience requires decision making that entails adapting to environmental changes, developing strategic orientations, and facing difficulties (Lengnick-Hall \& Beck, 2009).

In the same line, Mzid et al. (2019) argue that this level of strategic decision making to cope, adapt, and thrive can be reached by leveraging the family firm's adaptative capacity, strategic renewal, and appropriation capacity. The first dimension - adaptative capacity - refers to the application of strategies and routines to manage resources in challenging times, looking to adapt the capabilities to an uncertain environment and thus minimize the impact of the shocks (Mzid et al., 2019; Stallings, 2005). This situation frequently results in an inimitable adjustment originated from the family business owners' adaptative capacity (Danes, 2006), underlying the wish for continuity of family involvement in management (Mzid et al., 2019). The study by Landau (2007) and Stafford, Bhargava, Danes, Haynes, and Brewton (2010) supports this affirmation since their results indicated that disasters improve the family firm's response and in turn its sustainability.

The second dimension related to organizational resilience is a strategic renewal, or the family firm's skills to visualize the upcoming opportunities from an innovative view to propose solutions and reconsidering practices (Mzid et al., 2019). Finally, the third dimension is appropriation capacity, which consists of the proficiency by which firms use their past experiences to assume the postcrisis period in a way that allows them to emerge better prepared to face the new environment (Altintas \& Royer, 2009; Mzid et al., 2019). We concur with these dimensions of resilience and therefore our study focuses on them to analyze the subject family businesses' responses to the pandemic, identify which resources are used and respond to our first research question: How prepared are they to face an environmental shock such as the pandemic?

Regarding our second research question: Have contexts affected the family business response to COVID-19? To the best of our knowledge, there is very little research analyzing family firms' responses to disruptive events in different contexts. Brewton et al. (2010) conducted a comparative study of resilience in urban and rural family firms and tested that there are differences in their ability to adapt as a consequence of the differences in their cultural and community settings; for instance, intrinsic aspects of the industry, which vary significantly due to activities developed, consumer segments, budgets, competitors, and social structures (Brewton et al., 2010). Their results suggest that resources like social capital have a differentiated effect on family firms' resilience in the case of rural firms, but not on urban firms; however, federal help was negatively associated with family resilience for both types of firms. Those differences are explained by the fact that under a disruptive event family management adapts resources for both the family and the firm by incorporating changes aligned with their particular system (Danes, Haberman, \& McTavish, 2005).

Based on the above, Chrisman et al. (2011) pointed out that a better understanding of resilience is required because most of what we know is based on European and Anglo-American contexts, but its study on different settings may improve our understanding of family firms resources and capabilities and the specificity of their practices during an environmental shock. Our study serves that call.

\section{Methods}

\subsection{Sample}

According to De Massis and Kotlar (2014) to study family businesses, scholars must navigate through multiple levels of analysis to understand the family, the business, and the ownership dimensions, which constantly intertwine with one another. Therefore, the sample of our research consisted of five family members in two business families and three family businesses in the furniture industry in the 
USA, and in Colombia. The participants were not randomly selected, but chosen based on the industry and business similarity, their size, and four conditions that they fulfilled to be recognized as family businesses: 1) they are all beyond the first generation; 2) family ownership is $100 \%$ in all cases; 3 ) there is high involvement of the family in governance, and 4) the current owners have the intention to transfer the business to the next generation (Zellweger, 2017). In sum, family involvement in the businesses in our sample is very strong in both management and ownership. That is why the strategic decisions made by the family businesses during the pandemic are made by the corresponding business families. The Colombian business family owns a core business and a spin-off, founded by one of the second generation siblings and currently owned by him and his children. Both businesses are located in Medellin, the second-largest city in Colombia. The second business family is located in Michigan, USA, owning only one core business. Business presidents and one family board member were interviewed in all cases. Below, a brief description of the businesses is presented.

\subsubsection{The Colombian core family business ${ }^{1}$}

The core family business was founded in 1954 by a Colombian entrepreneur who started a movable furniture manufacturing business to serve institutional clients. In the beginning, he mainly focused on education seating, audience seating, and later, office furniture which has remained their focus, even though they have changed their business model to designing productive and friendlier standardized working spaces for home office, offices, education, health, and hospitality. They also have a business line by Projects in which they customize working spaces as needed. Mostly, their customers are institutional.

Regarding succession, the entrepreneur who had 11 children, transferred leadership to his eldest son, who run the business for over 11 years (up to 1987), then he stepped down so that one of his brothers took over. In 2005, the founder passed away, transferring equal ownership to all his children. It was before his passing that the second generation developed a family constitution in which they agreed that the family should not be employed by the company, and if any talented next-generation member was interested he/she would compete and be appointed by meritocracy after he/she would comply with the rules of entry as established in the constitution. This constitution also formalized the board of directors composed by two family members, one of them the Chair, the president, and two independent outsiders.

Until December, 2019, the company had a non-family president who stepped down and was replaced by another on-family interim president appointed by the board who used to serve as a consultant for the business. From that moment on the board has had a very active approach, meeting every month and permanently advising the interim

${ }^{1}$ We will refer to this as the Colombian core family business across the following sections. president as needed. Currently, the two family members serving at the board are the youngest second-generation sibling -one interviewee- and one of his nieces who has manufacturing and industry interests and background.

\subsubsection{The Colombian spin-off family business ${ }^{2}$}

When the eldest second-generation member stepped down as president of the core business in 1987, he remained as a shareholder and board member of the core family business and started his own business with his financial resources, but bringing the tacit knowledge and experience he had earned from his father and serving as the president of the core family business. The spin-off business focuses on furniture but has offered designs and furniture for the outdoors (parks, driveways, and landscapes), and larger spaces like audience seating and shopping centers. The spin-off is currently owned by the founder, his wife, and their three children, two sons and a daughter. He ran the company until 2016, when his youngest son took over as president, as he started serving as board Chairman.

Regarding the board, until 2018, they had an advisory board with two outsiders, but they decided to change the business model and go through a strategic renewal, so the advisory board changed to become a shareholders board. The reason for the renewal was mainly that the industry in their segment saturated, which shrunk their profits, so they decided to become more agile and flexible, as well as more efficient in terms of costs, particularly fixed ones, represented by labor and excess capacity. The president then decided to transition the business model to furniture design and not necessarily manufacturing, given that the company's brand and the family's reputation are valuable enough to sell special projects to clients, which are more profitable for the business. The president and the founderboard member were both interviewed.

\subsubsection{The American family business}

This family business was founded in 1944 focused on providing high-end furniture to firms that care about design. They have won prestigious awards over time, and their clients are mostly Fortune 500 companies. They focus on tables, particularly meeting tables manufactured with sustainable product design, and craftsmanship. The family business has had both family and non-family leaders across time. The current Chair of the board is a $3^{\text {rd }}$ generation family member, served as President on and off, alternating with a long-time employee while his eldest son was preparing to take over as president. The son took over his father in 2014, after being in the company for over 10 years. The board of directors is quasi-independent with two outsiders. The interviewees included the president and the Chairman.

As opposed to the Colombian business family, large with members from the second and third generation as the core business' owners and one independent, stand-alone spin-off owned by one of the second generation members

${ }^{2}$ We will refer to this family business as the Colombian spin-off. 
and his nuclear family, this business family owns one family business and is itself a small family with three owning family members, the senior third-generation member, who serves as Chair of the board, and his two sons who work at the business, one of them as the current president. Descriptors of the two business families and the three family businesses selected are presented in Table 1.

\subsection{Data collection}

To answer our research questions, this qualitative study followed a social constructivist approach with a case study design aimed to understand and interpret the implications of the pandemic and the consequential reactions and actions of the three family businesses studied, operating in the same industry in two very different contexts. A case study is a research strategy used to study a particular phenomenon within its real-life context (De Massis \& Kotlar, 2014). Family business scholars have called for these types of approaches, given that most of what we know in the field is based on quantitative data (Nordqvist et al., 2009), which is limited interpreting "why" and "how" questions (De Massis \& Kammerlander, 2020; De Massis \& Kotlar, 2014).

To endeavor methodological congruence (Morse \& Richards, 2002), we strived to preserve consistency and connectedness between our research questions, data collection, and analysis. For this, we conducted five semistructured interviews after examining the literature on RBV and resilience. On average, the interviews took between 45 minutes and an hour. The Colombian interviewees are a senior family and board member of the core business and the Chairman of the Colombian spinoff as well as its president. The American interviewees are the Chairman of the core business and its president.
The interviewees were informed in advance that their confidentiality and that of the firm would be protected. All interviews were recorded and transcribed.

Standardized questions initiated the interview to allow comparisons in terms of business model, market segments, revenues, employees, current leadership, and governance as presented in Table 1. After those, the open-ended questions asked focused on the before, during and after the pandemic, the actions and reactions on the pandemic, and the resilience of the family and the business. Regarding resilience, we specifically asked about the family and the business adaptive capacity, strategic renewal, and appropriation capacity, following Mzid et al. (2019) definitions and descriptions of each of the dimensions (See interview protocol in Table 2). As interviews were conducted, we focused on resources and capabilities in the questions; lastly, we wrapped up the interviews asking about the country's reactions to COVID-19, and particularly, how each interviewee felt that the context helped/restrained the family business to face the pandemic. The interview format allowed for follow-up questions, which improved the richness of the data and the comparison between business family's responses.

\subsection{Data analysis}

To analyze the data, both authors conducted content analysis in which the interviews were read, re-read, and reviewed to collect patterns and quotes from the interviewees related to each of the factors that denoted the how and why of the resilience capabilities signaled by Mzid et al. (2019) following a data categorization approach (De Massis \& Kotlar, 2014). Then, we compared and discussed our independent results and patterns for consensual validation (Creswell \& Poth, 2016).

Table 1. Business families description

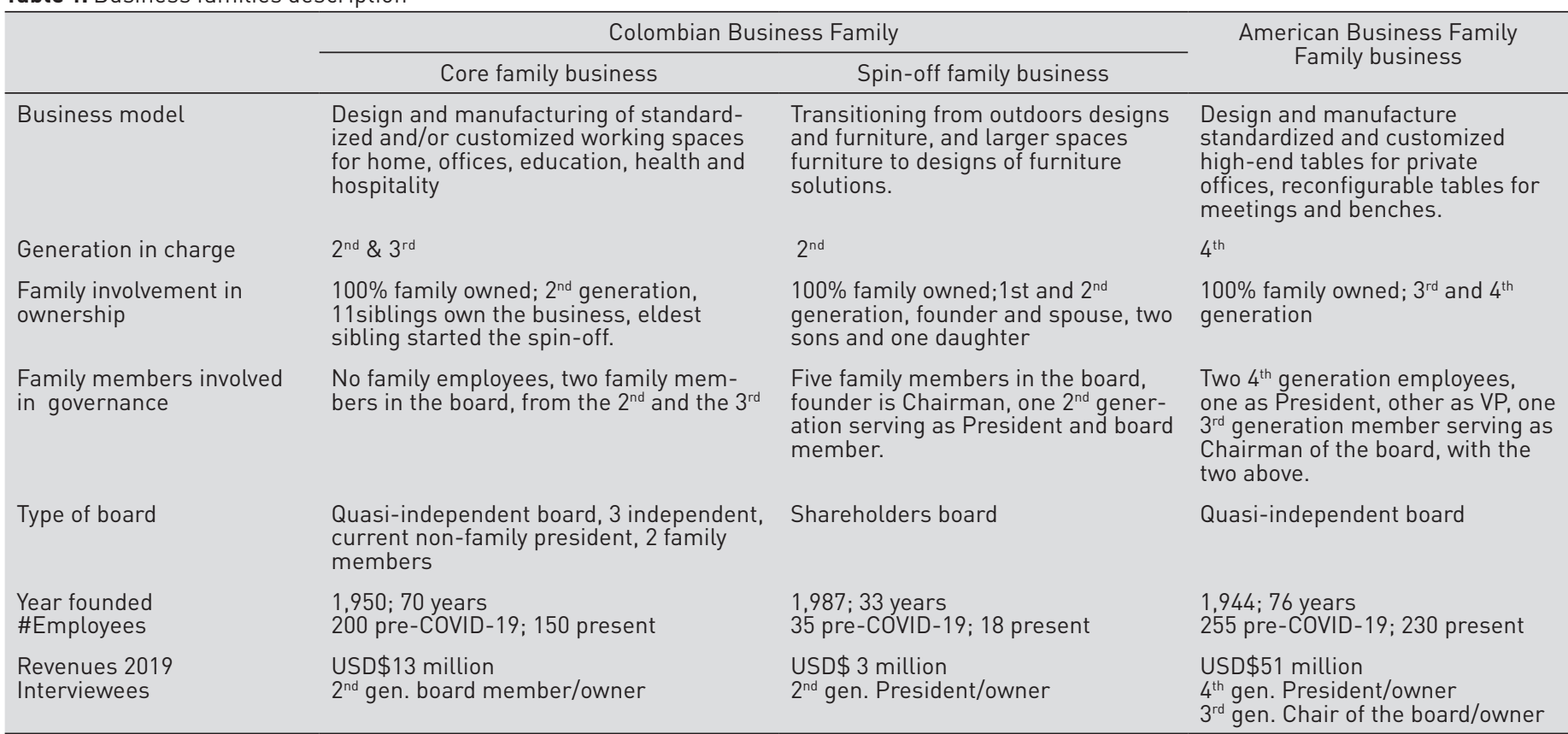

Source: own elaboration. 
As a consequence of this process, we found commonalities in almost all patterns identified; those two patterns in which there was not a coincidence were adaptive capacity and strategic renewal. We discussed and concurred that they occurred because adaptive capacity can lead to strategic renewal or vice versa and most importantly, it was the context that determined which one of the two resources came first, as we will further explain in our results discussion section. Next, we present the context analysis followed by the results.

\section{Context analysis}

As our research questions aim at comparing and contrasting family business reactions due to the pandemic, we provide a description and analysis of the contexts in which the sampled family businesses operated during COVID-19 (De Massis \& Kotlar, 2014).

\subsection{COVID-19 in the USA and the state of Michigan}

The first case was officially detected in the USA on January $21^{\text {st }}, 2020$, but it was until March $13^{\text {th }}, 2020$, when the national emergency was issued and a 50-billion-dollar fund for the emergency was allocated. By the end of March, the USA was leading the world in confirmed cases, and the federal government released a 2-trillion-dollar bill, in which loans at very low rates were offered for businesses to operate, as well as relief funds for individuals who were registered as taxpayers. At this time, the federal government decided not to issue national restrictions and policies, but let each state decide on them. By the first week of April, almost all the states in the East and West Coasts were in lockdowns, with critical situations in New York, Portland, and Los Angeles, respectively. Only essential businesses were allowed to operate, such as hospitals, grocery stores, pharmacies, utilities, health care, and commercial banks or financial institutions. By that time as well, just after a few weeks, 10 million Americans lost their jobs.
In general, the US response to the pandemic has been considered very weak worldwide. Most analysts concur that two factors affected the US response. First, the lack of a national response, the absence of a centralized national mandate and structure supporting and supplying states at need, since the pandemic was affecting the country at a staggering pace. Both coasts were hit first during the late winter-early spring, while the southern states were hit by the end of the spring and beginning of the summer, and so did the rural and central states. Instead, states made their own decisions and often competed with one another for supplies. Second, the presidential election in November politicized decision making resulting in contradictory messages about the pandemic, the recommendations, and the reopening process. The worst consequence is that the US never lowered the rate of infections below 20,000 cases per day, never flattening the curve. In contrast, the country increased the contagion rate to over 200,000 daily cases by December 2020, and it became the country with the highest death toll per capita in the world to nearly 320,000 in total (NYtimes, 2020).

One factor that supported businesses across the pandemic was the CARES Act and its Paycheck Protection Program (PPP), a law signed on April $24^{\text {th }}, 2020$, by the federal government to create a USD $\$ 659$ billion stimulus pack to provide funds for small businesses to pay up to 8 weeks of payroll costs including benefits (US Department of Treasury, 2020). By the end of June 2020, 5,338 small businesses had received support, 89 medium-sized, and 34 with assets over 50 billion to keep the unemployment rate under control (U.S. Small Business Administration, 2020). Even though the PPP helped, by the end of July 2020, the US economy had its worst results ever, showing a $32.9 \%$ drop, just three months after the crisis started (NPR, 2020). The unemployment rate went from $5 \%$ in January 2020, to nearly $15 \%$ in May 2020, to $7.9 \%$ at the beginning of October 2020 (NYtimes, 2020).

Table 2. Interview protocol

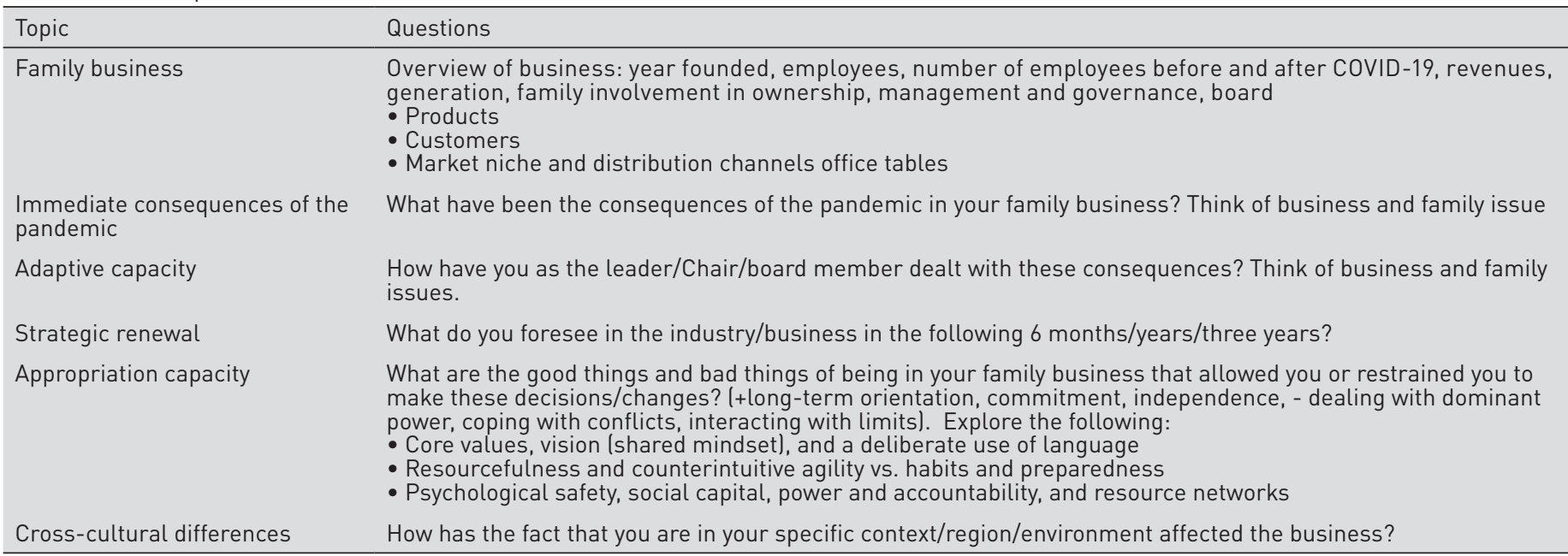

Source: own elaboration. 
By the end of 2020, the Dow Jones was at its highest but the stock market has been an emotional roller coaster from the very beginning of the pandemic, hitting its lowest ever as well, although many blame the President of the United States for it. Americans are spending less and saving more (CNN, 2020). The Congressional Budget Office is projecting a nearly USD \$7.9 trillion hit (after adjusting for inflation) to the GDP over the next decade, mostly represented by the energy and transportation sectors. In terms of the economy in the US, small business revenue is estimated to be down $20 \%$ since January 2020 , and expected to be up to $30 \%$ by the end of 2020 (Brookings, 2020).

As for Michigan, the state in which the American family business is located, it was hit hard by COVID-19, after the first case was confirmed in early March 2020. The causes of the large spread were associated firstly to Detroit's Metropolitan Airport late travel check and ban, combined with the international character of the auto industry and the fact that Wuhan, China, is an automotive hub as Detroit. Second, the democratic presidential primary, which leads to a large number of the population to in-person voting, and a republican presidential rally (Bridge Michigan, 2020a). The first stay at home order was issued on March 23 $3^{\text {rd }}, 2020$, which locked down all non-essential businesses, and was extended until May $28^{\text {th }}, 2020$, for individuals. Starting on May $11^{\text {th }}$, 2020, manufacturing workers were allowed to resume work, provided that facilities adopt safety measures to prevent contagion, i.e. social distancing and masks (Michigan State, 2020). Michigan's governor has been one of the strictest ones in the country, following CDC guidelines to the letter, and until the day of the submission of this paper, face-masks are required indoor and public places, and indoor gatherings over 25 people are forbidden if no social distancing is possible. This has let the state be able to flatten the curve of contagion and deaths in the last weeks of 2020, even though currently, cases are spiking, as it is all over the country due to the winter.

As for the state's economy, it was initially predicted that there was going to be a fiscal deficit of about USD $\$ 3$ billion, but forecasts are projecting it is going to be around USD\$ 1 billion. Most likely, the federal stimulus checks rendered to individuals, the PPP, and unemployment benefits have contributed to lessening the impact. The biggest challenge seems to be unemployment, as more than 1 million jobs were lost in the middle of the crisis, which may take years to reduce (Bridge Michigan, 2020b). By later December 2020, Congress approved a second stimulus pack, providing a new round of federal aid for individuals and businesses as well.

\subsection{The Colombian setting and the pandemic}

In Colombia, the first official case was confirmed by the national government on March $6^{\text {th }}, 2020$. The national government declared a Health Emergency throughout the country, initially until May $30^{\text {th }}, 2020$. The following preventive measures were implemented: cancellation of all public events of over 50 people, mandatory preventive isolation (stay at home order), and closure of non-essential businesses. The initial response made Colombia stand out as a country with stronger and earlier measures (El Nuevo Siglo, 2020).

However, these measures resulted in a collapse in production, and a drastic drop in households and businesses incomes, and cash flows. Consequently, the country had large liquidity and credit needs at all levels (companies, banks, households). Therefore, the Central Bank of Colombia responded with several monetary policy interventions: decreasing interest rate from $4.5 \%$ to $1.75 \%$, reducing banks' reserves requirements, injecting liquidity into the financial system through treasury bonds, and public and private debt, renewing forward maturities, and increasing in international reserves by 2 billion dollars (Banco de la República, 2020).

The national government provided resources for the health system, facilitated the acquisition of medical equipment for decentralized testing, but also provided liquidity to the hospital network so that the system could have the capacity to respond. A return of sales taxes was also implemented for the most vulnerable population, relief in credit payments and guarantees so that small and mediumsized companies had easy access to different credit lines through the Ministry of Finance and Public Credit. Likewise, the government guaranteed the supply chain with essential goods (Presidencia de la República, 2020) and access of micro, small and medium-sized companies to credit lines with the financial system to maintain their payroll and minimize negative effects on employment. Nevertheless, by April 2020, 5.5 million people lost their jobs, reaching its highest level in the last 20 years. Meanwhile, in the same month, the number of employees fell to the levels observed 14 years ago (2006), with the greatest impact on women and people under 28 years old (El Nuevo Siglo, 2020). Considering the above, the emergency will cost between $7 \%$ and $8 \%$ of GDP.

\subsection{Furniture industry dynamics}

The business families studied are dedicated to the furniture industry, particularly office furniture, although they have also expanded to institutional furniture. The furniture industry is divided into target segments. The first is B2C in which the customers go to a distribution center or multipurpose store, online or face-to-face (Wal-Mart, Amazon, etc.), or to a specialized store dedicated exclusively to a need (home furniture such as IKEA or Wayfair). The second is B2B, which includes either furniture for commercial establishments, like restaurants and offices. The office segment entails computer desks, swivel chairs for the office, and workspaces furniture for all sizes and purposes, standardized and/or customized. According to the Statista Consumer Outlook (2020), global office furniture accounted for $8 \%$ of the furniture industry revenue in 2019. That same year, office furniture sales increased by $4.5 \%$ compared to 2018 (USD $\$ 114$ billion). The industry has had a compound annual growth of $5.1 \%$ since 2012 (Statista, 2020). This expansion in office furniture is boosted by innovative products and the growth in the use of high-end ergonomic furniture in office spaces. By the end of 
2020 , revenues are expected to suffer a contraction of around $6 \%$ compared to 2019, due to COVID-19 (Statista, 2020). Despite the pandemic, the segment is expected to recover its growth rate worldwide from 114 billion in 2019 to 132 billion in 2023 (Statista, 2020).

In a regional comparison, the USA represents $6 \%$ of the global market share and South America 8.3\% (no data available for Colombial. The impact of COVID-19 in the industry is not expected to be strong 10 in the USA, $0.1 \%$ in South America) (Statista, 2020).

\section{Results}

We present the results categorized by each of the three dimensions of resilience: adaptive capacity, strategic renewal, and appropriation capacity (Mzid et al., 2019), comparing resources and capabilities deployed during the pandemic, outcomes, and contexts in each dimension.

\subsection{Adaptive capacity}

Our analysis of the interviews indicates that the Colombian family firms and the American one provide evidence of adaptive capacity to face the negative effects of COVID-19 on their businesses and the furniture industry. Adaptive capacity implies the adjustment of the family and the business resources and capabilities to face the shock induced by COVID-19, which initially put the three family businesses in a lockdown since they were not considered essential businesses. This capacity was observed in both the family and the business and confirmed by all respondents, and probably was the dimension with more data collected.

One similarity, in terms of the resources and capabilities deployed to adapt was access to capital to fund the payroll, supported by both the Colombian and the American governments. The three family companies accessed the very favorable low-interest loans for payroll. However, that access was rather different and its use as well. The American family business followed the institutionalized process deployed by the federal government to access and get the PPP funds, while the Colombian core and spinoff businesses straightforwardly got them because of the family reputation and creditor connections. About this, the Chairman of the Colombian spin-off mentions: "We called the bank, we asked for the loan and we got it. They were trying to lend more money to us. We said no, but still, the money has helped us these months. We hope that eventually it'll be condoned, but who knows..." Instead, the American family business president states: "We applied to the loan early in case we needed working capital, but we never actually used it." Reinforcing this point, the Chair of the board of this American family business indicates "We've been in a strong financial condition, the boys [the President and his brother, his sons] have continued to operate the same way, so they've continued to keep the debt very low and keep the cash very high so that we're able to do all the things that we need to do..." This shows that they used the loan as a safety net just in case they needed it to fulfill their obligations, rather than as working capital, a clear difference on adaptive responses, provided by the context.

The board member of the Colombian core business mentioned that the pandemic helped them become more efficient. In his words:

"With the lockdown, the company reduced its costs $50 \%$, particularly payroll, and it became more frugal in the sense that we're currently living with $75 \%$ of the budget, as a direct consequence of the drop in orders...Somehow due to the pandemic we're adapting, saving and improving because the market shut down too."

This adaptation was confirmed by the president of the Colombian spin-off as well: "COVID-19 in a way helped, since orders completely stopped in March, we delivered the last one we had and we closed...but if some job came up, we worked and got the order out, no matter what it was and who it was." This indicates that both the Colombian core business and the spin-off found silver linings by adapting; the larger core business by gaining efficiencies and the smaller one by adapting production to the point of even manufacturing face-masks to supply and support the emergency. The spin-off president states:

"A friend who owns a medical supplies business called me and said Colombia is out of face-masks. Then he says, listen, I need to make them, can you help me? I said, I don't know, so he replied saying: brother, I need them, I'll pay you now and you give me 1,000 next week."

He figured it out and managed to deliver them, get some cash, despite being shut down.

On this same point, the spin-off Chairman signaled the capacity of the firm to adapt their production to the need of the moment, given that malls and universities, their main clients, canceled orders before the pandemic: "We started looking for things to do, the face-masks came and we found sewing machines, and the machinery destined to do furniture upholstering was used to help with the process as well. We also produced and sold scrubs". Given the strong financial position of the American business, they did not need to look for alternative revenue sources or look for operational efficiencies beyond business operations.

The American family business did not mention efficiencies as a consequence of adaptation. One explanation for this could be that the orders for Colombian family businesses went directly to zero, while in the American business decreased around 30\%. They even experienced a bottleneck when they returned to work to manufacture and deliver pre-pandemic orders falling behind, since as opposed to the Colombian cases, orders were not canceled.

Another difference in adaptation between the family businesses in the two countries was their reaction towards their employees. The Chair of the American family business mentions "You know when we shut down, we furloughed our hourly workers, we paid I think USD $\$ 80$ or 90,000 to those hourly associates as a bonus before we furloughed them so it didn't count towards their right to unemployment and that allowed them to bridge kind of a two-week gap between 
applying for unemployment and getting the money. We call that kind of the "[Family Business name]stimulus" The American president also states in this regard: "We were able to keep all of our employees financially secure and we did it through a combination of some of the people we helped them file for unemployment and that looked like it was the best route for them financially." Moreover, when asked why they did not furlough every employee, the American President states without even thinking: "...because it was the right thing to do." Having said that, the above does not mean that the Colombian core and spin-off family businesses did not care about their workforce; they have had strategic changes started before the pandemic that explains their workforce reductions, but they will be discussed in the following section.

When asked about the supply chain problems that almost all businesses experienced around the world during the pandemic, the Colombian family businesses mentioned they occurred but were not deeply affected by them, while the American family business felt concerned, but not because of the supply chain, but because of the staggered shutdown process the country went through, with states fully open while others were in lockdown. In the words of the American Chairman: "Yeah you know there's a lot of logistical consequences. You know it's been interesting we've had only one challenge with one supplier. But we struggled when some of the states were open and some of the states were not. I think when we were shut down... [Rivals in other states] were running right, so you know they had an opportunity to figure stuff out while we were down." This caused them anxiety during the pandemic, but they did not elaborate since the consequences might not be long term, if there are any. Either way, it was the country's reaction to the shock that caused concern in this case.

In sum, during COVID-19, all family businesses reflected adaptive capacity by deploying the following resources and capabilities: access to capital and workforce changes. However, their purposes and outcomes were different. As well, only the Colombian family businesses reflected flexibility and agility, however, each one had different outcomes. While the core business gained efficiencies, the spin-off looked and got alternative revenue sources, most likely explained by the differences in sizes. Regarding context, it seems that developed and more institutionalized context give the family business stability, while the uncertainty of the Colombian setting combined with COVID-19 explains their more radical responses as will be corroborated in the strategic renewal dimension next (Table 3).

\subsection{Strategic renewal}

The second dimension of resilience in family firms is a strategic renewal, which was particularly evident in the case of the Colombian core and spin-off family businesses, but not evidenced in the American family firm. The pandemic caught the Colombian spin-off in the middle of a strategic reshaping and transition, given that, as mentioned earlier, the family was not comfortable with the profitability of their business model. In the words of the president: "It was not our intention to have labor reductions because of COVID-19, but we wanted to reduce labor costs as a consequence of the business model transition we started two and a half years ago. That gave us an advantage compared to other businesses with similar models and larger payrolls, since we were already reducing."

As mentioned earlier, the idea is to change the business model to design and outsource manufacturing. In the words of the spin-off president "We plan to stop manufacturing as much as possible and be focused on design. Colombia is not a country for manufacturing unless you have large economies of scale."

The spin-off's Chairman also added that after the facemasks and scrubs venture, "My son came up with the idea to design portable and easy to assemble isolated workspaces for adults and kids to be sold fully online. He named them clickywork... at the beginning no one knew the brand and we weren't associated with it, but little by little, promoting it in social media it's been growing in three months." Regarding this new product, the president mentions "the idea came to me because my wife always complains when I assemble stuff she buys because it takes me too long and I always have spare parts for no reason, and I'm always upset because she's not pleased after all the work I put into the assembly. Therefore, I figured that people might need working spaces with protections from COVID-19 that they can assemble in two minutes, with no tools or screws required, but simply just assembling by pressure. I had the workforce and machinery to manufacture by demand, and there it is."

Interestingly, the product line was launched and a month later the president noticed a nearby company copied the design and was selling knock-off versions. His reaction was: "When I realized that a company nearby was selling our patented designs, I paid them a visit with my lawyer. When we sat in his office, the guy looked at me very worried; since I started the conversation by saying that I'd sue him, which would be a loss for them if he kept doing that. So, I offered him to keep doing it, I'd give him the design, he could produce them as much as he wanted, but he should pay us a royalty. He looked surprised, we closed the deal and we're both happy... See, we're about design, not manufacturing."

Besides the above, the president added: "and moving forward, I could go to the US and make the same proposition to anyone who wants to manufacture our designs and/or sell them on Amazon. I already sent 100 units to a contact and he'll sell them on Amazon, and we'll see. To anyone, I'd say yes, go ahead, and just pay me royalties."

Under this new strategic umbrella as well, the Colombian spin-off also capitalized on unproductive assets as the president states "Our facility is very large and it made sense when we were a manufacturing company, but with the new business model, there's no need to have such large place in the most commercial location in the city. I rather rent some of that space at a very profitable price than waste it. I'd rent the whole thing and move my stuff someplace else for that matter, but my dad was reluctant. The pandemic helped me since the revenues dropped to zero, so I told my dad, I need to make payroll, renting some space is useful and he finally agreed, so 
in a way, COVID-19 helped me accelerate the new business model because my dad let me go through with the changes he felt less comfortable with."

The core Colombian company and its business family, in general, have been considering strategically moving out of the country. Their main concern is related to the political uncertainty of the country with the upcoming presidential election in 2022, which raised concerns among private business owners, since the political left was close to win before and it is gaining leverage, especially with the low-income population that has been deeply affected by COVID-19 and is the vast majority. Moreover, Venezuela's experience under the control of a socialist president has exacerbated these fears. They have also focused more on design and are strongly thinking of increasing their international presence, strengthen their innovation and design capabilities to start moving business and eventually capital out of the country. In synthesis, the pandemic precipitated the decisions that the core family business had been considering before.

Lastly, when asked about strategic renewal, the American family business president said the following: "We have what we need to face the pandemic, we're financially strong, we will experience a drop in sales but there is no need to change everything... We're meeting with the board more often, planning for the next three months, and waiting until things are less uncertain and the pandemic effects have settled down... Things are going to change in the new normal, but not as radical to panic".

In sum, strategic renewal for these family businesses has been more context-driven. The Colombian family businesses are changing a lot, not only because of COVID-19 but taking advantage of COVID-19, to accelerate pre-COVID-19 renewal strategic decisions (See results in table 3). The American family business is waiting, since according to his president, this is not time to panic and change, it's time to wait and see, their strong financial position allows them to do that.

\subsection{Appropriation capacity}

This resilience dimension entails the ability to use past experiences to handle the post-COVID-19 effectively, which means better prepared for the "new normal" (Altintas \& Royer, 2009; Mzid et al., 2019). As expected, the oldest family firms were the ones who deployed resources and capabilities on this dimension. i.e. the Colombian core family firm and the American family business.

In the Colombian core family business case, the outcome was more family-focused, than business-focused. The core business board member mentioned how they are preparing the next generation as a product of the experiences he and his siblings have gone through, both positive and negative. In his own words "When I came back to the board, I knew some of my siblings wanted me to come back as Chair, but I suggested my niece should be the Chair. That way we start giving stronger involvement to the next generation, as we all know we should do. They all went along with me." Besides that, he mentioned that given that the company was in a sound financial situation and given the dividend sacrifices his siblings have been experiencing in the past few years because of their strategic renewal, this year, despite the contraction, he expects stable profits. Therefore, he has been discussing with the board the possibility of compensating the family with no dividend reduction, since it has provided the business with patient capital for years, particularly since some of the siblings have been hit hard by the pandemic. The core business board member explains: "Since we began the strategic changes, five years ago, dividends have been lower, so now we need to discuss and vote in the board to increase dividends, the family needs that and they've been supporting these changes for long, we need to payback."

The American family business was particularly interested in keeping good relationships with its stakeholders, when asked about supply chain problems upstream and downstream faced by the business during the pandemic. In the words of the president: "We care about the people, that's a big part of [our response] and the second part is that we felt we care about our customers and our customers needed to be able to talk to us [about] what was going on, and we continue to work with customers and help them on designing new projects. We do a lot of specials for people so we still help them design special tables ... even during the shutdown".

As well, they were focusing on not making radical changes and planning in the short term due to the increased uncertainty. The president mentions: "Right, so we have a three-year plan and the first thing we did is, we said hey you know in times of great uncertainty you have to focus on the short-term right because you just don't know what's going to happen so you know, we pulled back our capital expenditures and we said, look you know we're just going to plan out 90 days at a time."

The answers given by the business family members in the two countries regarding appropriation capacity show that the American family firm has experienced several disruptive crises, which allow them to use their tacit knowledge, network, financial capital, and planning capacity to be more prepared and plan to focus their efforts in the short-run, considering the current uncertainty and volatility that hinders good long-term planning. In the case of the Colombian core family business, this capacity has allowed them to support family members in need and be more prepared to face the crises (Results in Table 3).

\section{Discussion}

The literature has found that family businesses are indeed resilient (Brandon-Jones et al., 2014; Brewton et al., 2010; Mzid et al., 2019). However, it has fallen short of explaining the how and why of their reactions to environmental disruption. Consequently, using the RBV of the firm (Barney, 1991), and based on the resilience dimensions suggested by Mzid et al, (2019) adaptative capacity, strategic renewal, and appropriation capacity, we studied three businesses owned by two business families, operating in the same industry, in two 
very different settings: Colombia and Michigan in the USA.

Our findings indicate that as expected, the pandemic has put a lot of pressure on family firms' adjustment to the new normal, a situation that is also affected by firm size and age, the business model, and the context in which the businesses operate, as contingency factors affecting the resources and capabilities configuration and their reactions to disruptions, i.e. their resilience (Brandon-Jones et al., 2014).

The most prominent resilience dimension identified in all family firms is adaptative capacity. However, how the owning families deployed this capacity was quite different, concurring with the contingent RBV perspective (Danes, 2006). As well, we found evidence of resources and capabilities orchestration (Sirmon et al., 2011), in this case, forced by the environment. In the Colombian spin-off, this event forced flexibility and product diversification, despite a workforce reduction, there is evidence of adaptative responsiveness and sustainability in the middle of a crisis (Landau, 2007; Stafford et al., 2010). In the American firm, the adaptation was focused on protecting the business and its stakeholders despite the contraction in the income and the orders. This scenario shows that adaptative capacity is present in both cases, but is affected by contextual factors, which implies a context-specific configuration of resources and capabilities, suggesting a contingent familiness (Habbershon \& Williams, 1999).
In the Colombian cases, access to capital as a resource was used for working capital, while in the American case, it was used as insurance. This result provides evidence that despite leveraging the same resource, both the drivers and its use are completely different. Accordingly, this finding expands Brewton et al. (2010) results, beyond the rural versus urban resilience in family firms to emergent versus developed economies.

Strategic renewal, the second dimension related to organizational resilience (Mzid et al., 2019) occurred in both the Colombian core business and the spin-off, but not as a result of COVID-19. This abrupt disruption precipitated the strategic changes that the business family was considering pre-COVID-19, even supporting and accelerating a decision already made by the current generation that was being reluctantly accepted by the previous generation. In the Colombian core business case, the business family is considering an expansion into new markets and diversification, while the spin-off is radically changing its business model. This conscious reaction to the pandemic is a signal of resilience due to the presence of an idiosyncratic organizational system of resources such as innovation and risk propensity in the family that was definitive in the business response (Olson et al., 2003).

Table 3. Outcomes and drivers of resilience dimensions' resources and capabilities

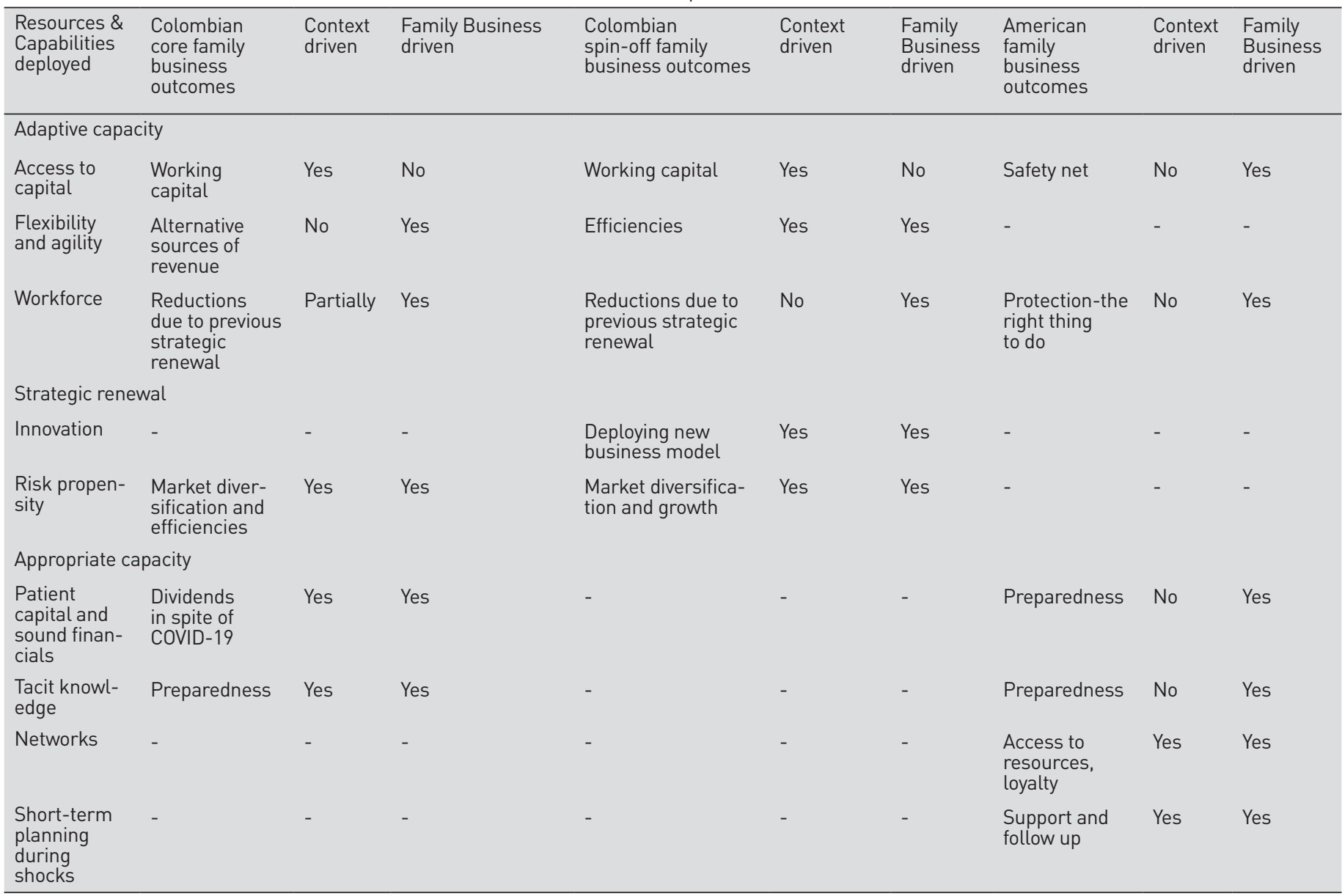


The absence of strategic renewal on the American family business in the pandemic, and its manifestation on the Colombian cases, supports our view of a contingent familiness.

Finally, appropriation capacity (Mzid et al., 2019) was manifested in the Colombian core business and the American family business, the long-established and larger firms. This capacity is developed from the knowledge and expertise that give them the experience of already lived compromising and defiant events, which has prepared them to stand in front of a shocking event and survive. In both the Colombian and the American core businesses resources such as patient capital, sound financials, tacit knowledge, and short-term planning have supported their disruption preparedness, while in the American family business case networks as a resource have also been deployed to support customers (Altintas \& Royer, 2009; Mzid et al., 2019). In this resilience dimension, the reactions of families have been more internally driven, even though context-based differences were manifested.

In sum, our study expanded the RBV of the firm suggesting that there is a contingent familiness that is deployed in times of crisis and remains idiosyncratic, not only between family businesses but among contexts. These findings also suggest that family business resilience is manifested in heterogeneous ways and owning families may deploy resources, mostly driven by the contexts in which they operate.

\section{Conclusions}

In sum, we expanded on the RBV contingent approach (Brush \& Artz, 1999) and corroborated the critique of this theory of the firm being context isolated (Rau, 2014), suggesting a contingent familiness (Habbershon \& Williams, 1999). Contexts matter and future research should focus on the applicability of our theoretical assumptions across more contexts and even pivot into new theories of the family firm that can explain our diverse family business resilience findings.

We also gained a more in-depth understanding of family business resilience by capturing resources and capabilities specificity, the context in which they are used, their rationale, and the associated outcomes. Nordqvist et al. (2009) and DeMassis and Kamerlander (2020) have stated the need to expand qualitative approaches that let us know more about the why and how than about the existence of specific relationships, which are the products of quantitative studies. We believe we served that purpose. Having said that, our exploratory study has the limitation of having only two business families analyzed in two different countries, even though they are operating in the same industry; this limitation prevented us from making suggestions, but future research could also focus on expanding this study by including more family business cases to be able to propose a model that could later be tested quantitatively.

Last but not least, this study provided evidence of family businesses heterogeneity (Memili \& Dibrell, 2019) and allowed us to show evidence that generalizations and judgments on family businesses reactions, attitudes, behaviors, resources, and capabilities constitute an oversimplification that feels like mixing apples and oranges since they all come in all shapes and sizes. Factors such as country, industry, business, and family altogether and their influence on the family business system differently affect their resilience. Having said that, a deeper understanding of those resources and capabilities that are commonly leveraged across contexts is needed, constituting another future research option.

This study allowed us to explore family business reactions while facing COVID-19. Learning about the particularities of the responses and the resources used can help us shape better practices to be ready if something like this occurs again, which most likely will, but more importantly, to set our eyes on what we can control and our minds on what we can deploy, all else is out of our hands. In this sense, we concur with Fareed Zakaria about the pandemic: "We are often advised to think big. But maybe we need to start thinking small" (Zakaria, 2020, p. 2).

\section{Conflict of interest}

The authors declare no conflict of interest.

\section{References}

Acquaah, M., Amoako-Gyampah, K., \& Jayaram, J. (2011). Resilience in family and nonfamily firms: an examination of the relationships between manufacturing strategy, competitive strategy and firm performance. International Journal of Production Research, 49(18) 5527-5544. https://doi.org/10.1080/00207543.2011.563834

Altintas, G., \& Royer, I. (2009). Renforcement de la résilience par un apprentissage post-crise : une étude longitudinale sur deux périodes de turbulence. Management, 4(2), 266-293. https://doi.org/10.3917/mana.124.0266

Banco de la República. (2020). Línea de tiempo medidas Banrep COVID-19 | Banco de la República (banco central de Colombia). Retrieved October 16, 2020, from:

https://www.banrep.gov.co/es/medidas-junta-directiva-covid19

Barney, J. (1991). Firm Resources and Sustained Competitive Advantage. Journal of Management, 17(1), 99-120. https://doi.org/10.1177/014920639101700108

Brandon-Jones, E., Squire, B., Autry, C., \& Petersen, K. J. (2014). A Contingent Resource-Based Perspective of Supply Chain Resilience and Robustness. Journal of Supply Chain Management, 50(3), 55-73. https://doi.org/10.1111/jscm.12050

Brewton, K. E., Danes, S. M., Stafford, K., \& Haynes, G. W. (2010). Determinants of rural and urban family firm resilience. Journal of Family Business Strategy, 1(3), 155-166. https://doi.org/10.1016/j.jfbs.2010.08.003

Bridge Michigan. (2020a). Michigan economy is stronger than expected amid pandemic. Thank the stimulus. Bridge Michigan. Retrieved October 16, 2020, from: https://www.bridgemi.com/business-watch/michigan-economystronger-expected-amid-pandemic-thank-stimulus

Bridge Michigan. (2020b). Why did coronavirus spread so fast in Michigan compared to neighbors? I Bridge Magazine. Retrieved October 16, 2020, from: https://www.bridgemi.com/michigan-health-watch/ why-did-coronavirus-spread-so-fast-michigan-comparedneighbors

Brookings. (2020). Ten Facts about COVID-19 and the U.S. Economy Retrieved October 16, 2020, from: https://www.brookings.edu/ research/ten-facts-about-covid-19-and-the-u-s-economy/

Brush, T. H., \& Artz, K. W. (1999). Toward a contingent resourcebased theory: The impact of information asymmetry on the value of capabilities in veterinary medicine. Strategic Management Journal, 20(3), 223-250. https://doi.org/10.1002/(SICI)10970266(199903)20:3<223::AID-SMJ14>3.0.CO;2-M 
Chrisman, J. J., Chua, J. H., \& Steier, L. P. (2011). Resilience of Family Firms: An Introduction. Entrepreneurship Theory and Practice, 35(6), 1107-1119. https://doi.org/10.1111/j.1540-6520.2011.00493.x

CNN. (2020). US economic recovery after the coronavirus pandemic and recession - CNN Business. Retrieved October 16, 2020, from: https://edition.cnn.com/business/us-economic-recovery-coronavirus

Creswell, J. W., \& Poth, C. N. (2016). Qualitative inquiry and research design: Choosing among five approaches. Thousand Oaks: Sage Publications.

Danes, S. M. (2006). Tensions Within Family Business-Owning Couples Over Time. Stress, Trauma, and Crisis, 9(3-4), 227-246. https://doi.org/10.1080/15434610600854244

Danes, S. M., Haberman, H. R., \& McTavish, D. (2005). Gendered Discourse about Family Business. Family Relations, 54(1), 116-130. https://doi.org/10.1111/j.0197-6664.2005.00010.x

Danes, S. M., Lee, J., Amarapurkar, S., Stafford, K., Haynes, G., \& Brewton, K. E. (2009). Determinants of family business resilience after a natural disaster by gender of business owner. Journal of Developmental Entrepreneurship, 14(4), 333-354. https://doi.org/10.1142/S1084946709001351

Danes, S. M., Loy, J. T.-C., \& Stafford, K. (2008). Business Planning Practices of Family-Owned Firms within a Quality Framework. Journal of Small Business Management, 46(3), 395-421. https://doi.org/10.1111/j.1540-627X.2008.00250.x

Danes, S. M., Rueter, M. A., Kwon, H.-K., \& Doherty, W. (2002). Family FIRO Model: An Application to Family Business. Family Business Review, 15(1), 31-43. https://doi.org/10.1111/j.1741-6248.2002.00031.x

De Massis, A., \& Kammerlander, N. (2020). Handbook of Qualitative Research Methods for Family Business. Cheltenham: Edward Elgar Publishing Limited.

De Massis, A., \& Kotlar, J. (2014). The case study method in family business research: Guidelines for qualitative scholarship. Journal of Family Business Strategy, 5(1), 15-29. https://doi.org/10.1016/j.jfbs.2014.01.007

Donthu, N., \& Gustafsson, A. (2020, September 1). Effects of COVID-19 on business and research. Journal of Business Research, 117, 284-289. https://doi.org/10.1016/j.jbusres.2020.06.008

Duran, P., Kammerlander, N., Van Essen, M., \& Zellweger, T. (2016). Doing more with less: Innovation input and output in family firms. Academy of Management Journal, 59(4), 1224-1264. https://doi.org/10.5465/amj.2014.0424

El Nuevo Siglo. (2020). Los efectos del Covid-19 en la economía de Colombia I El Nuevo Siglo. Retrieved October 16, 2020, from: https://www.elnuevosiglo.com.co/articulos/06-2020-los-efectosdel-covid-19-en-la-economia-de-colombia

Gómez-Mejía, L. R., Haynes, K. T., Núñez-Nickel, M., Jacobson, K. J. L., \& Moyano-Fuentes, J. (2007). Socioemotional Wealth and Business Risks in Family-controlled Firms: Evidence from Spanish Olive Oil Mills. Administrative Science Quarterly, 52(1), 106-137. https://doi.org/10.2189/asqu.52.1.106

Grant, R. M. (1991). The Resource-Based Theory of Competitive Advantage: Implications for Strategy Formulation. California Management Review, 33(3), 114-135. https://doi.org/10.2307/41166664

Habbershon, T. G., \& Williams, M. L. (1999). A Resource-Based Framework for Assessing the Strategic Advantages of Family Firms. Family Business Review, 12(1), 1-25. https://doi.org/10.1111/j.1741-6248.1999.00001.x

Habbershon, T. G., Williams, M., \& MacMillan, I. C. (2003). A unified systems perspective of family firm performance. Journal of Business Venturing, 18(4), 451-465. https://doi.org/10.1016/S0883-9026(03)00053-3

Landau, J. (2007). Enhancing Resilience: Families and Communities as Agents for Change. Family Process, 46(3), 351-365. https://doi.org/10.1111/j.1545-5300.2007.00216.x

Lengnick-Hall, C. A., \& Beck, T. E. (2009). Resilience capacity and strategic agility: Prerequisites for thriving in a dynamic environment. In Resilience capacity and strategic agility: Prerequisites for thriving in a dynamic environment (pp. 39-69). San Antonio, TX: UTSA: College of Business.
Memili, E., \& Dibrell, C. (2019). A Brief History and Look to the Future of Family Business Heterogeneity. In E. Memili \& Dibrell (Eds.), The Palgrave handbook of Heterogeneity of Family Firms (Palgrave M, pp. 1-15). Cham: Palgrave McMillan.

Michigan State. (2020). Coronavirus - Michigan Data. Retrieved October 16, 2020, from: https://www.michigan.gov/coronavirus/0,9753,7-406-98163_98173---,00. html

Moen, P., \& Wethington, E. (1992). The Concept of Family Adaptive Strategies. Annual Review of Sociology, 18(1), 233-251. https://doi.org/10.1146/annurev.so.18.080192.001313

Morse, J. M., \& Richards, L. (2002). Readme first for a user's guide to qualitative methods. Thousand Oaks: Sage publications.

Mzid, I., Khachlouf, N., \& Soparnot, R. (2019). How does family capital influence the resilience of family firms? Journal of International Entrepreneurship, 17(2), 249-277. https://doi.org/10.1007/s10843-018-0226-7

Nordqvist, M., Hall, A., \& Melin, L. (2009). Qualitative research on family businesses: The relevance and usefulness of the interpretive approach. Journal of Management and Organization, 15(3), 294-308. https://doi.org/10.5172/jmo.2009.15.3.294

NPR. (2020). GDP Drops At 32.9\% Rate, The Worst U.S. Contraction Ever: Coronavirus Live Updates: NPR. Retrieved October 16 2020, from: https://www.npr.org/sections/coronavirus-liveupdates/2020/07/30/896714437/3-months-of-hell-u-s-economysworst-quarter-ever

NYtimes. (2020). Jobs Report Shows Further Slowdown in U.S. Economic Recovery - The New York Times. Retrieved October 16, 2020, from: https://www.nytimes.com/2020/10/02/business/economy/ september-jobs-report.html

Olson, P. D., Zuiker, V. S., Danes, S. M., Stafford, K., Heck, R. K. Z., \& Duncan, K. A. (2003). The impact of the family and the business on family business sustainability. Journal of Business Venturing, 18(5), 639-666. https://doi.org/10.1016/S0883-9026(03)00014-4

Patel, P. C., \& Fiet, J. 0. (2011). Knowledge Combination and the Potential Advantages of Family Firms in Searching for Opportunities. Entrepreneurship Theory and Practice, 35(6), 1179-1197. https://doi.org/10.1111/j.1540-6520.2011.00497.x

Patterson, J. M. (2002). Understanding family resilience. Journal of Clinical Psychology, 58, 233-246. https://doi.org/10.1002/jclp.10019

Paul, J. J., Winter, M., Miller, N. J., \& Fitzgerald, M. A. (2003). CrossInstitutional Norms for Timing and Sequencing and the Use of Adjustment Strategies in Families Affiliated with Family-Owned Businesses. Marriage and Family Review, 35, 167-191. https://doi.org/10.1300/J002v35n01_10

Penrose, E. (1959). The Theory of the Growth of the Firm. Londres: Oxford university press.

Presidencia de la República. (2020). Gobierno Nacional le anuncia al país las primeras medidas económicas y sociales, en el marco de la declaratoria del Estado de Emergencia. Retrieved October 16, 2020, from:

https://id.presidencia.gov.co/Paginas/prensa/2020/ Gobierno-Nacional-medidas-economicas-sociales-EstadoEmergencia-200318.aspx

Rau, S. (2014). Resource-Base View of Family Firms. In Sage (Ed.), The SAGE Handbook of Family Business (pp. 321-338). https://doi.org/https://doi.org/10.4135/9781446247556.n16

Sirmon, D. G., \& Hitt, M. A. (2003). Managing Resources: Linking Unique Resources, Management, and Wealth Creation in Family Firms. Entrepreneurship Theory and Practice, 27(4), 339-358. https://doi.org/10.1111/1540-8520.t01-1-00013

Sirmon, D. G., Hitt, M. A., Ireland, R. D., \& Gilbert, B. A. (2011). Resource Orchestration to Create Competitive Advantage. Journal of Management, 37(5), 1390-1412. https://doi.org/10.1177/0149206310385695

Stafford, K., Bhargava, V., Danes, S. M., Haynes, G., \& Brewton, K. E. (2010). Factors Associated with Long-Term Survival of Family Businesses: Duration Analysis. Journal of Family and Economic Issues, 31(4), 442-457. https://doi.org/10.1007/s10834-010-9232-1 
Stallings, R. A. (2005). Disaster and the theory of social order. In In What is a Disaster? (pp. 145-164). Londres: Routledge.

Statista. (2020). Furniture Report 2020 - Office Furniture I Statista. Retrieved October 16, 2020, from: https:/www.statista.com/ study/48887/furniture-report-office-furniture/

Steier, L. (2005). Executive succession in entrepreneurial business. In I. M. Hitt \& D. Ireland (Eds.), The Blackwell encyclopedic dictionary of entrepreneurship (2nd ed., pp. 125-128). Oxford: Blackwell.

U.S. Small Business Administration. (2020). Paycheck Protection Program (PPP) Report. Retrieved October 16, 2020, from: https:// www.sba.gov/sites/default/files/2020-07/PPP Results - Sunday FINAL.pdf
US Department of Treasury. (2020). The CARES Act Provides Assistance to Small Businesses. Retrieved October 16, 2020, from: https:// home.treasury.gov/policy-issues/cares/assistance-for-smallbusinesses

Wernerfelt, B. (1984). A resource-based view of the firm. Strategic Management Journal, 5(2), 171-180. https://doi.org/10.1002/smj.4250050207

Zakaria, F. (2020). Ten lessons for a post-pandemic world. New York: W.W. Norton \& Company.

Zellweger, T. (2017). Managing the Family Business: Theory and Practice (Vol. 1). Cheltemham: Edward Elgar. 